\title{
Effect of riparian vegetation roots on development of meander bends in Tarim River, Northwest China
}

\author{
Guo-An $\mathrm{Yu}^{1, *}$, Zhiwei $\mathrm{Li}^{2}$, He Qing Huang ${ }^{1}$, Weiwei $\mathrm{Yao}^{3}$ \\ ${ }^{1}$ Key Laboratory of Water Cycle and Related Land Surface Processes, Institute of Geographic \\ Sciences and Natural Resources Research, Chinese Academy of Sciences, Beijing 100101, China \\ 2 School of Hydraulic Engineering, Changsha University of Science \& Technology, Changsha \\ 410114, China \\ ${ }^{3}$ Key Laboratory of Environmental Remediation, Institute of Geographic Sciences and Natural \\ Resources Research, China Academy of Sciences, Beijing, 100101, China
}

\begin{abstract}
Meandering channel with distorted bends develops along the Tarim River, the longest dryland river in China. The river bank and bed is majorly composed of coarse silt and fine sand and almost none clay content, making the bank strength very low. The development of meander bend in such environment hence is somehow irrational. We preliminarily investigate the effects of riparian vegetation root on bend development in this region through examining the root cohesion and its enhancement on bank stability. In-situ measurements and sampling of roots from local typical riparian vegetation (i.e., populous, Tamarix, and Phragmites Australis) were conducted to obtain root parameters like diameter and root area ratio. Local bend curvature corresponding to sampling sites are also obtained. BSTEM model is used to quantitatively estimate the effects of different root conditions on improving channel bank strength. Four vegetation root scenarios were modelled, i.e., tree (populous), shrub (Tamarix), grass (Phragmites Australis) and no root. The results show that root supplies effective cohesive reinforcement for the channel bank and enhances the bank safety factors $\left(F_{s}\right)$. Riparian vegetation should be a necessary condition for development of meandering channel in Tarim River.
\end{abstract}

\section{Introduction}

Rivers are natural feedback systems whose planform morphologies in alluvial reaches reflect three fundamental ingredients: flow energy, sediment calibre and supply, and riparian vegetation [1-4]. While early theoretical attempts for fluvial morphodynamics emphasized flow (stream power) and sediment controls, the significance of riparian vegetation is now recognized [3, 5-6].

\footnotetext{
*Corresponding author: yuga@igsnrr.ac.cn
} 
Riparian vegetation (with roots) have profound effects on channel morphology, impacting upon total channel width, braiding index and relative mobility of channels. This occurs through several mechanisms (mechanical, hydrologic), particularly by increasing both resistance to flow and bank strength [7-8], which affect both the sediment delivery to and sediment transport in channels.

Vegetation roots increase bank strength and the stability of channel margins [9-11]. Soil without plant roots (grass, shrub or trees) has high compressional strength, but little tensile strength. Root fibers increase the tensile strength and elasticity of soil by transferring shear stress in the soil matrix to tensile resistance in the fibers [12], helping to distribute stresses and therefore enhancing the bulk shear strength of the soil [9-11, 13]. Studies showed that vegetation can have a particular influence on braided rivers (e.g., [14]), due to its role in forming well-defined banks and stabilizing bars. The intermingled roots of plants tend to bind the soil together in a monolithic mass and contribute to strength by providing an additional apparent cohesion [15].

Unique fluvial morphology develops along the Tarim River, the longest allogenic and perennial dryland river in an extreme arid region in China. Though the channel planform pattern of the upper reach of the river is dominantly braided, in the middle and lower reaches meandering channel with quite distorted bends develops. The sinuosity index of the meandering channel ranges 1.6 to 2.2 , with high spatial variability and lateral migration rate [16]. Strangely, sediment composition of the bank is quite even with majorly coarse silt and fine sand and almost none clay content, the strength of the channel bank is consequently very low and prone to be scoured or even collapsed if riparian vegetation is lacking. The development of the meander bends in such environment is hence somehow irrational. Little is known on the causes underlying the development of the meander planform pattern in Tarim River. It is not clear how the root enhances stability of channel bank composed with silt/sand bank and how it helps to balance the scouring rate at the concave bank and deposition rate at the convex bank.

The aim of the present work is to understand the role of riparian vegetation root on the cohesive reinforcement and stability of non-cohesive channel bank (with coarse silt and fine sand), and to assess the effects of root on development and maintain of meander bends.

\section{Research area and methods}

\subsection{Research area}

The Tarim River is a dryland river that flows within the Tarim basin, the largest inland river basin in China (Figure 1). The climate of the continental basin is extremely dry. Although annual precipitation in the mountainous headwater regions can reach approximately $200-500 \mathrm{~mm}$, within the basin it is only $50-80 \mathrm{~mm}$, and just $10 \mathrm{~mm}$ in the central desert area [17].

The Tarim River can be regarded as an allogenic (exotic) river since its surface runoff is derived predominantly from snowmelt and glacier-melt in the surrounding high mountains, rather than from local precipitation [18]. The long-term mean annual runoff to the main stem Tarim River is about $4.7 \times 10^{9} \mathrm{~m}^{3}$, with an annual sediment load of approximately $22.8 \times 10^{6} \mathrm{t}$, based on hydrometric data from the past five decades (1960 to 2011) at Alar (AL), the most upstream gauging station on the main stem of the river. Discharge and sediment load decrease in the downstream direction due to transmission losses. The channel planform pattern of the upper reach (reach site 1, Fig. 1) of the river is braided, however, in the middle and lower reaches (reach sites 2 to 5, Fig. 1) meandering channel with quite distorted bends develops (Fig. 2). 


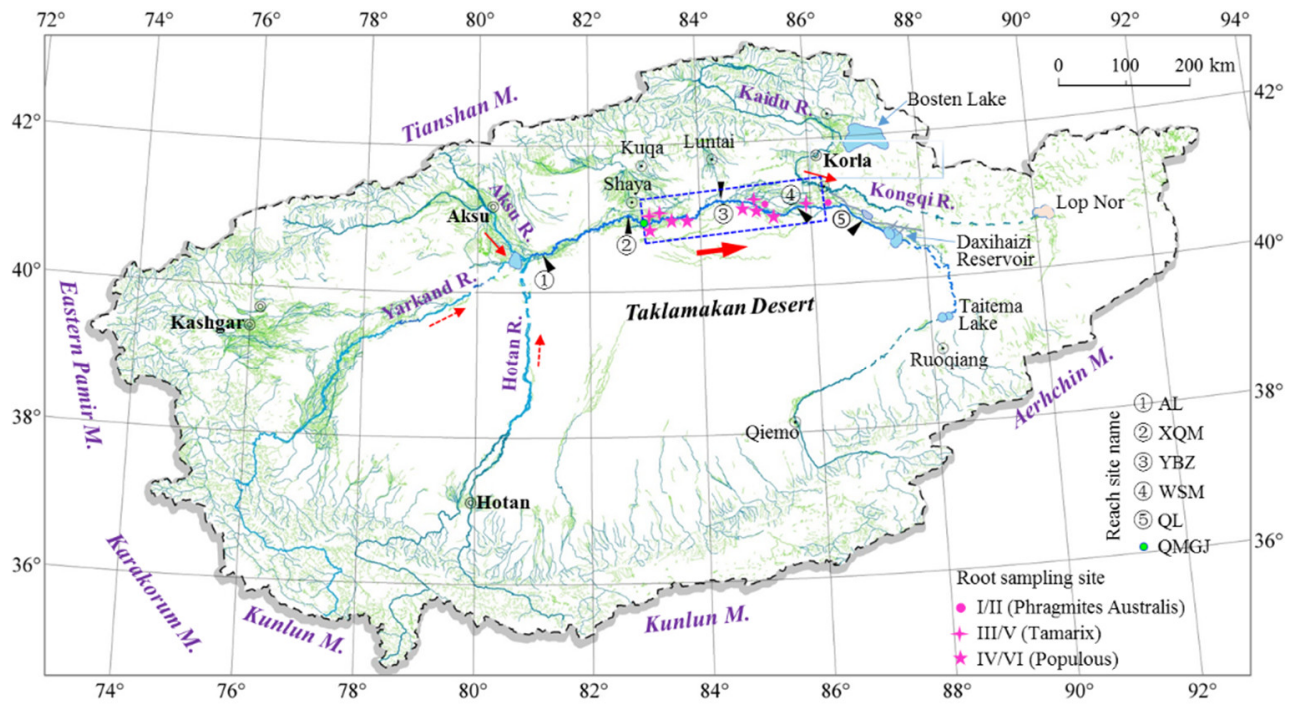

Fig. 1. The Tarim River and the analysed meandering reach (blue dashed rectangle)

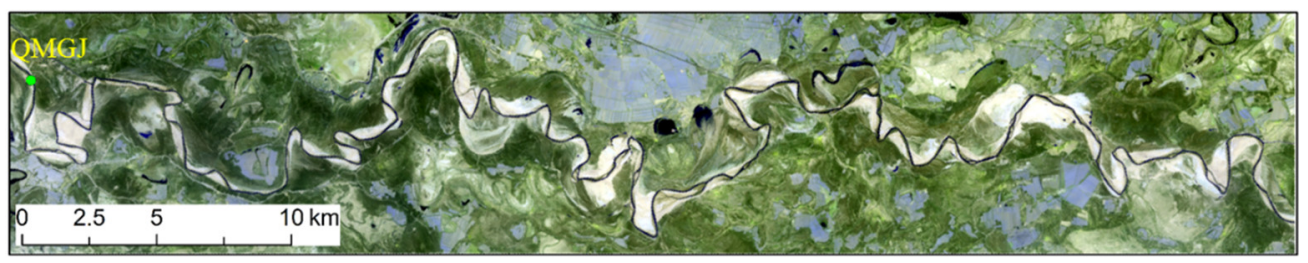

Fig. 2. A section of meandering channel with distorted bends downstream of QMGJ (Remote sensing image taken on May 25, 2014)

\subsection{Methods}

In-situ measurements and sampling of roots from local typical riparian vegetation (i.e., populous trees, Tamarix, and Phragmites Australis) along meandering channel of the river were conducted (Fig. 3, Table 1). Root samples were taken at sites I, II and III by digging square or rectangle holes with certain sizes horizontally into vertical banks, at other sites exposed root is directly sampled since bank soil (silt, sand) has been eroded by flowing water. Sampled roots were brought to lab to obtain root parameters like length, root diameter and root area ratio. Root tensile strength is estimated referring to literature [12, 19-20]. Root area ratio (RAR) is computed as $A_{r} / A$, where $A_{r}$ is the total cross-sectional area of all roots and $\mathrm{A}$ is the area of soil in the sample count.

Sediment deposits were also sampled from banks and river bed at sites of root survey points (Site I to VI). The size distributions of sediment samples were obtained with a laser scattering particle analyser (MasterSizer 2000).
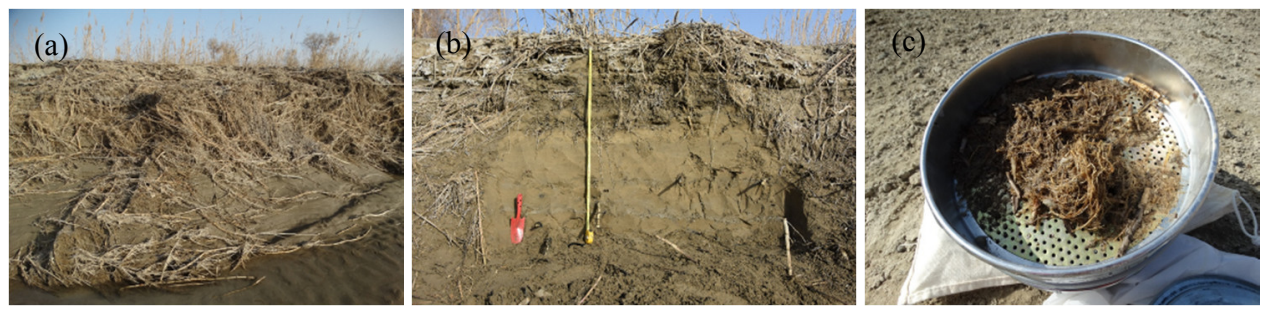

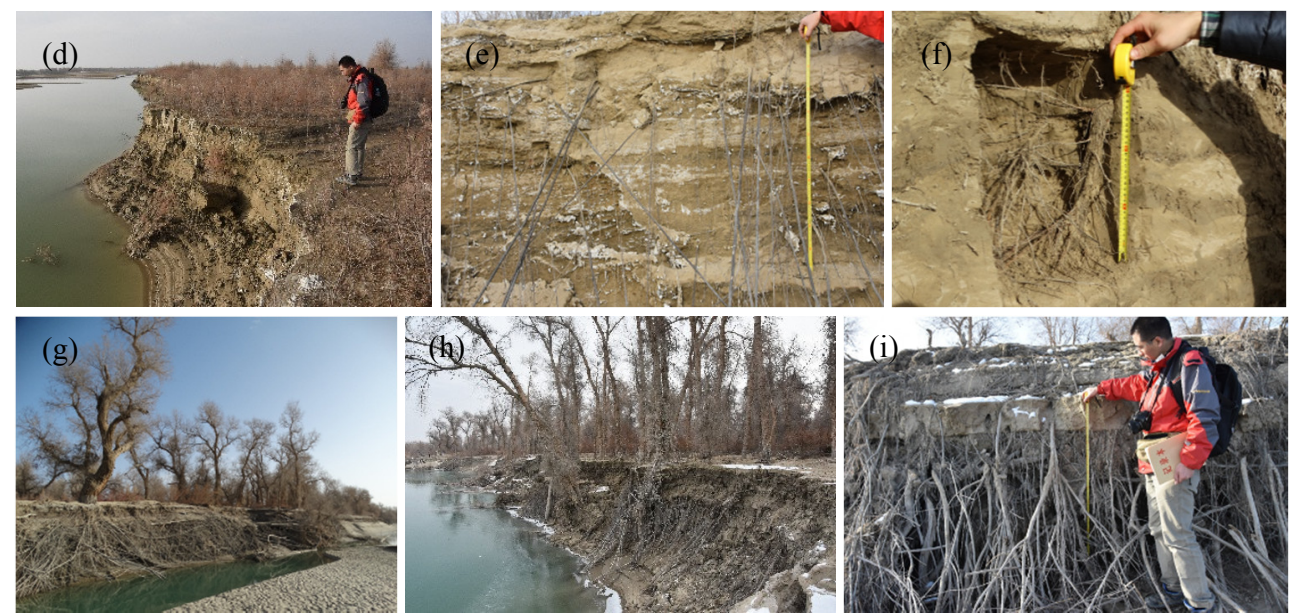

Fig. 3. Measurement and sampling of roots of typical riparian vegetation along Tarim River. (a, b, c) grass (Phragmites Australis); (d, e, f) shrub (Tamarix); and (g, h, i) tree (populous).

Table 1. Samples of roots of three typical vegetation species in six different sites.

\begin{tabular}{|c|c|c|c|c|}
\hline $\begin{array}{l}\text { Vegetation } \\
\text { species }\end{array}$ & Sites & Locations & $\begin{array}{l}\text { Size for root sampling } \\
{[\text { length } \times \text { width } \times(\text { depth })]} \\
(\mathrm{m})\end{array}$ & $\begin{array}{l}\text { Number } \\
\text { of roots }\end{array}$ \\
\hline \multirow{2}{*}{$\begin{array}{c}\text { Grass / } \\
\text { Phragmites } \\
\text { Australis }\end{array}$} & I & $\begin{array}{l}41^{\circ} 03 ' 05.24 \text { '” } \\
86^{\circ} 0628.48^{\prime \prime} \mathrm{E}\end{array}$ & $0.3 \times 0.4 \times(0.15)$ & - \\
\hline & II & $\begin{array}{l}41^{\circ} 09 ' 20.41^{\prime \prime} \mathrm{N} \\
84^{\circ} 57^{\prime} 03.39 \text { ' }\end{array}$ & $0.3 \times 0.3 \times(0.2)$ & - \\
\hline \multirow[b]{2}{*}{$\begin{array}{l}\text { Shrub / } \\
\text { Tamarix }\end{array}$} & III & $\begin{array}{l}40^{\circ} 58 ' 27.80 " \mathrm{~N} \\
85^{\circ} 288^{\prime} 30.31 \text { 'E }\end{array}$ & $0.3 \times 0.3 \times(0.2)$ & - \\
\hline & V & $\begin{array}{c}\text { Around } \\
40^{\circ} 56,52.00 ” \mathrm{~N} \\
82^{\circ} 53 \text { ' } 12.40^{\prime \prime} \mathrm{E}\end{array}$ & $\begin{array}{l}2.0 \times 2.0 \\
2.0 \times 1.5 \\
2.2 \times 1.5 \\
1.0 \times 0.8 \\
\end{array}$ & $\begin{array}{c}30 \\
105 \\
157 \\
90 \\
\end{array}$ \\
\hline \multirow{5}{*}{$\begin{array}{c}\text { Tree / } \\
\text { Populous }\end{array}$} & \multirow{3}{*}{ IV } & $\begin{array}{l}41^{\circ} 12 ' 12.34 \text { '” } \\
84^{\circ} 21^{\prime} 43.33^{\prime \prime} \mathrm{E}\end{array}$ & $1.0 \times 1.0$ & 114 \\
\hline & & $\begin{array}{l}41^{\circ} 12^{\prime} 08.51^{\prime \prime} \mathrm{N} \\
84^{\circ} 21^{\prime} 44.37^{\prime \prime} \mathrm{E}\end{array}$ & $1.0 \times 1.0$ & 62 \\
\hline & & $\begin{array}{l}41^{\circ} 12^{\prime} 04.51 \text { 'N } \\
84^{\circ} 21^{\prime} 48.65^{\prime \prime} \mathrm{E}\end{array}$ & $2.0 \times 3.0$ & 42 \\
\hline & \multirow[b]{2}{*}{ VI } & Around & $2.0 \times 1.2$ & 434 \\
\hline & & $\begin{array}{l}40^{\circ} 56 ' 52.93 \text { 'N } \\
82^{\circ} 522^{\prime} 43.90^{\prime \prime} \mathrm{E}\end{array}$ & $1.8 \times 1.1$ & 55 \\
\hline
\end{tabular}

BSTEM model is used to quantitatively estimate the effects of different root conditions on improving channel bank strength. Basic parameters are determined through field investigation (Table 2). Four vegetation root scenarios were modelled, i.e., tree (populous), shrubs (Tamarix), grass (Phragmites Australis) and no root.

Table 2. Basic parameters used in the BSTEM model

\begin{tabular}{cccccccc}
\hline $\begin{array}{c}\text { Bank } \\
\text { height } \\
(\mathrm{m})\end{array}$ & $\begin{array}{c}\text { Bank } \\
\text { slope } \\
\left({ }^{\circ}\right)\end{array}$ & $\begin{array}{c}\text { Length } \\
\text { of bank } \\
\text { toe }(\mathrm{m})\end{array}$ & $\begin{array}{c}\text { Slope } \\
\text { of bank } \\
\text { toe }\left({ }^{\circ}\right)\end{array}$ & $\begin{array}{c}\text { Channel } \\
\text { gradient } \\
(\mathrm{m} / \mathrm{m})\end{array}$ & $\begin{array}{c}\text { Water } \\
\text { depth } \\
(\mathrm{m})\end{array}$ & $\begin{array}{c}\text { Eroding } \\
\text { time }(\mathrm{d})\end{array}$ & $\begin{array}{c}\text { Bank } \\
\text { material }\end{array}$ \\
\hline 3 & 70 & 1 & 30 & 0.0001 & 1 & 30 & Erodible silt \\
\hline
\end{tabular}


A parameter, bend curvature $C$, is introduced, defined as the ratio of the channel centreline length $L_{m}$ to the neck channel width $B_{m}$. The simple method approximately reflects the bend curvature of a single meander [c.f., 16].

\section{Results}

\subsection{Hydrodynamic featutres}

Daily flow discharge at the YBZ gauging station (site (3) in Fig. 1), located in the middle of the study reach, showing that the flood season mainly in July to September, and annual flood peaks normally in August (Fig. 4). The mean annual discharge $\left(Q_{m}=71.9 \mathrm{~m}^{3} / \mathrm{s}\right)$ is much higher than the median flow discharge $\left(Q_{50}=15.6 \mathrm{~m}^{3} / \mathrm{s}\right)$, and the large positive skewness ( $c s=2.71$, Table 3$)$, indicating that the discharge distribution is asymmetric, that is, low flow events occur more frequently than moderate and high flow events. The suspended sediment concentration is not very high and sediment load mainly concentrates in flood season (Table 3).

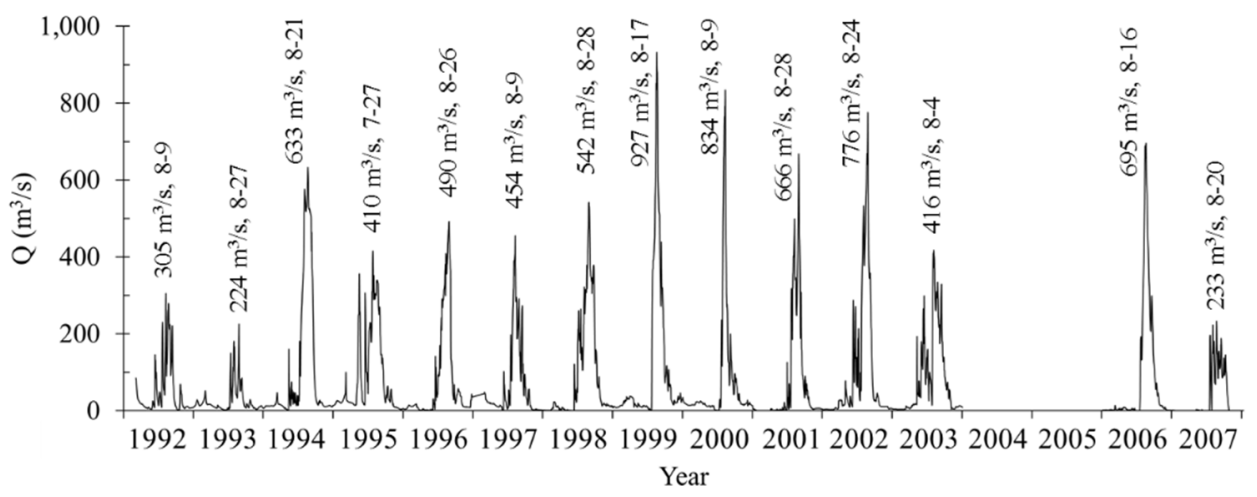

Fig. 4. Daily flow discharge at YBZ gauging station during 1992-2007, the maximum flow discharge in each year and the corresponding date were also marked.

Table 3. Flow and sediment characteristics in the study reach ${ }^{*}$

\begin{tabular}{|c|c|c|c|c|c|c|c|c|c|}
\hline \multicolumn{7}{|c|}{ Flow } & \multicolumn{3}{|c|}{ Suspended sediment } \\
\hline Ran & $Q_{m}$ & $Q_{50}$ & $Q_{f}$ & $Q_{n f}$ & $c v$ & $c s$ & $S S C_{m}$ & $S S C_{f}$ & $S S C_{n f}$ \\
\hline $0 \sim 932.0$ & 71.9 & 15.6 & 222.9 & 19.8 & 1.80 & 2.71 & 5.43 & 6.99 & 1.71 \\
\hline
\end{tabular}

"Flow data series: 1992-2007, YBZ gauge station (no data for 2004 and 2005). No data of suspended sediment at YBZ, alternatively, data from a gauge station about 30km downstream of YBZ is shown for reference, data series 1964-1971.

Range: Minimum $\sim$ Maximum daily flow discharge;

$Q_{m}$ and $Q_{50}$ : Mean and median flow discharge of the analyzed flow data, respectively;

$Q_{f}$ and $Q_{n f}$ : Mean flow discharge in flood (July-September) and non-flood season (October-June), respectively;

$c v$ and $c s$ : Coefficient of variation and Skewness of the analyzed flow data;

$S S C_{m}$ : Mean suspended sediment concentration over the analyzed years $\left(\mathrm{kg} / \mathrm{m}^{3}\right)$;

$S S C_{f}$ and $S S C_{n f}$. Mean suspended sediment concentration in flood and non-flood season, respectively.

Sediment from the banks and river bed is mainly composed of coarse silt and very fine sand (Fig. 5). The sediment composition is quite homogeneous with a sorting index (here we use $\left.\varphi=D_{80} / D_{20}\right)$ typically ranging between 1.4-1.6, lacking in clay content and with sparse riparian vegetation. In general, though no much difference, sediment composition of the channel bed is a little bit coarser than that of banks, and the clay content of channel bed 
is even lower than that of banks. Hence, the Tarim River channel is very unstable and prone to frequent lateral migration (and even cutoff) due to very low river bank strength.

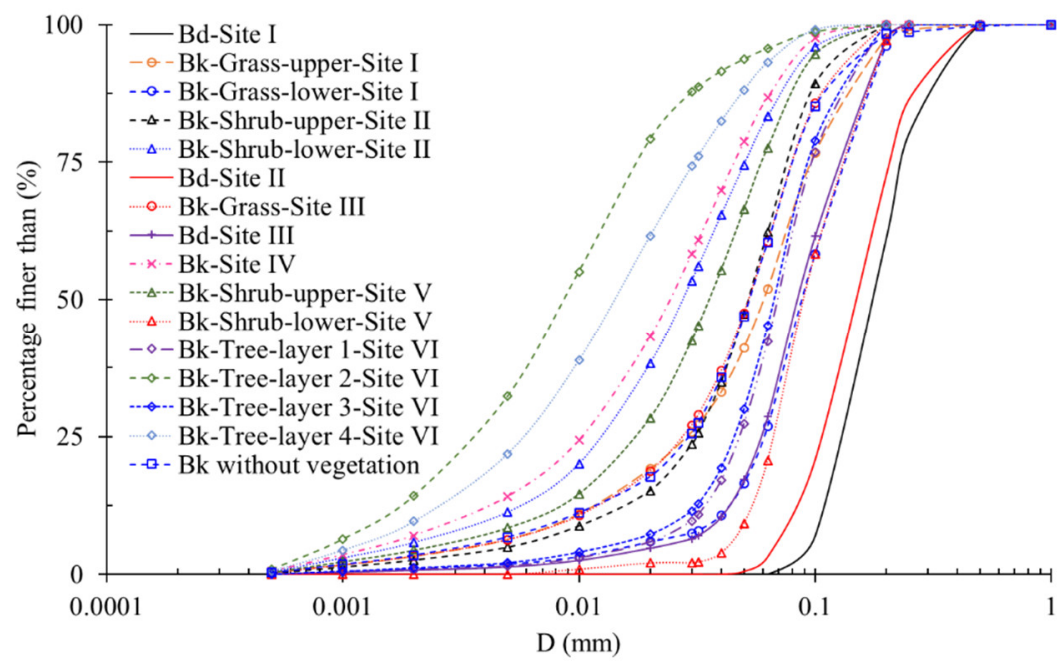

Fig. 5. Sediment composition of bed and banks with different riparian vegetation (grass, shrub and tree) along the studied reach (Bd-bed, Bk-bank)

\subsection{Sampled roots and bend curvature}

The physical characteristics (diameter, root area ratio) of the sampled vegetation roots in six sites is shown in Table 4. Banks with Populous trees have the highest root area ratio (RAR), while banks with Tarmarix have the lowest root area ratio (RAR).

Table 4. Physical characteristics of three typical vegetation species.

\begin{tabular}{|c|c|c|c|c|c|c|c|}
\hline \multirow{2}{*}{$\begin{array}{l}\text { Vegetation } \\
\text { species }\end{array}$} & \multirow{2}{*}{ Sites } & \multicolumn{3}{|c|}{ Root diameter $(\mathrm{mm})$} & \multirow{2}{*}{$\begin{array}{c}\text { RAR } \\
(\%)\end{array}$} & \multirow{2}{*}{$\begin{array}{l}\text { Local bend } \\
\text { curvature } \\
\text { C }\end{array}$} & \multirow{2}{*}{ Comments } \\
\hline & & Range & mean & $c v$ & & & \\
\hline \multirow{2}{*}{$\begin{array}{l}\text { Grass / } \\
\text { Phragmites } \\
\text { Australis }\end{array}$} & I & $\begin{array}{c}0.47- \\
11.5\end{array}$ & 3.47 & 0.78 & 0.19 & 1.49 & $\begin{array}{l}\text { Only grass, develops on } \\
\text { left bank, mobile sand } \\
\text { dune on right bank }\end{array}$ \\
\hline & II & $\begin{array}{c}0.24- \\
5.57\end{array}$ & 2.96 & 0.71 & 0.94 & 8.77 & Grass and tree \\
\hline \multirow{5}{*}{$\begin{array}{l}\text { Shrub / } \\
\text { Tamarix }\end{array}$} & III & $\begin{array}{c}0.27- \\
4.47\end{array}$ & 1.6 & 0.68 & 0.05 & 1.81 & Shrub and tree \\
\hline & \multirow{4}{*}{ V } & $5-12$ & l & l & 0.19 & \multirow{4}{*}{1.28} & \multirow{4}{*}{$\begin{array}{c}\text { Only shrub, on left bank, } \\
\text { downstream of braided } \\
\text { reach }\end{array}$} \\
\hline & & $1-18$ & 2.17 & 1.30 & 0.34 & & \\
\hline & & $1-10$ & 2.13 & 0.97 & 0.11 & & \\
\hline & & $1-6$ & $\sim 2$ & / & 0.3 & & \\
\hline \multirow{5}{*}{$\begin{array}{c}\text { Tree / } \\
\text { Populous }\end{array}$} & \multirow{3}{*}{ IV } & $\begin{array}{l}1.3- \\
12.4\end{array}$ & 3.21 & 0.90 & 0.58 & \multirow{3}{*}{1.73} & \multirow{3}{*}{ Only tree } \\
\hline & & $\begin{array}{l}1.2- \\
23.6\end{array}$ & 3.89 & 1.23 & 0.52 & & \\
\hline & & $\begin{array}{l}4.6- \\
58.6\end{array}$ & 22.7 & 0.63 & 1.13 & & \\
\hline & \multirow{2}{*}{ VI } & $1-25$ & 3.68 & 0.95 & 0.67 & \multirow{2}{*}{1.28} & \multirow{2}{*}{$\begin{array}{l}\text { Only tree, on the right } \\
\text { bank, downstream of } \\
\text { braided reach }\end{array}$} \\
\hline & & $6-55$ & 15.35 & 0.50 & 1.08 & & \\
\hline
\end{tabular}


Local bend curvature $(C)$ of six sampled river channel differs with different riparian vegetation (Table 4). For channel banks with single vegetation species (site IV/tree/Populous, site V/shrub/Tamarix and site I/grass/Phragmites Australis), $C$ values are in order corresponding to vegetation species of tree $>$ grass $>$ shrub. One other interesting information in Table 4 shows that, river bank with root of single vegetation species (sites I, $\mathrm{V}$, IV and VI) normally has lower bend curvatures than bank with root of multiple vegetation species, for example, site II with grass (Phragmites Australis) and tree (Populous), or site III with Shrub (Tamarix) and tree (Populous). This may indicates the combination of roots of different vegetation species may have better effects on maintenance of bank stability, and be conducive to develop relatively stable while distorted meander bend.

\subsection{Bank stability improved by roots}

The output from the BSTEM model based on six scenarios (no vegetation and single vegetation species, Table 5) shows different cohesion due to roots $\left(C_{r}\right.$, or cohesive forces added) and safety factors $\left(F_{s}\right)$ of river bank. All the three root conditions have more or less improvement on bank strength and stability, compared to bank without root. Bank with root of Populous trees have high $C_{r}$ and the highest $F_{s}$ values, indicating effective enhancement on channel stability. Bank with grass (Phragmites Australis) also has high cohension reinforcement due to root (the $C_{r}$ value ranks the second), though the $F_{s}$ is not high, the possible reason may be the low tensile strength of the grass root. Bank with single vegetation species of Tamarix has the lowest cohension reinforcment $\left(C_{r}\right.$ value). The results basically accord with the local bend curvature $(C)$ shown in Table (4), indicating root plays important role on development and maintenance of meander bends along the middle reaches of Tarim River.

Table 5. Cohesive forces added $\left(C_{r}\right)$ and safety factors $\left(F_{s}\right)$ under different root scenarios calcuated using BSTEM.

\begin{tabular}{cccc}
\hline Scenarios & $F_{s}$ & $\begin{array}{c}C_{r} \\
(\mathrm{kPa})\end{array}$ & Stability condition \\
\hline No vegetation & 0.54 & 0 & Not stable \\
Phragmites Australis & 1.06 & 89.6 & Relative stability \\
Tamarix 1 & 1.97 & 13.5 & Metastability \\
Tamarix 2 & 1.67 & 10.6 & Metastability \\
Populous 1 & 3.69 & 91.0 & Relative stability \\
Populous 2 & 2.87 & 66.3 & Relative stability \\
\hline
\end{tabular}

\section{Conclusions}

Root of the riparian vegetation supplies effective cohesion reinforcement for the soil of the channel bank and enhances the channel bank safety factors $\left(F_{s}\right)$. The non-cohesive bank with roots have obvious enhancement on channel bank strength than bank without any root. This constrains the lateral scouring of channel bank and is conducive to develop meander bends. Riparian vegetation hence plays an important role for developing and sustaining of meander bends in this silt-sand composited highly erodible channel in the Tarim River.

This study was supported by the National Natural Science Foundation of China (NSFC, Nos. 41571009; 41661144030; 91547112; 41330751). 


\section{References}

1. R. Kellerhals, M. Church, Proceedings of the International Large River Symposium (Canadian Special Publication of Fisheries and Aquatic Science, 1989)

2. C.R. Twidale, Earth-Sci. Rev. 67 (2004)

3. A. Gurnell, N. Surian, L. Zanoni, Aquat. Sci. 71 (2009)

4. M.G. Kleinhans, Prog. Phys. Geog. 34 (2010)

5. D. Corenblit, E. Tabacchi, J. Steiger, A.M. Gurnell, Earth-Sci. Rev. 84 (2007)

6. D. Corenblit, A. Baas, G. Bornette, J. Darrozes, S. Delmotte, R.A. Francis, A.M. Gurnell, F. Julien, R.J. Naiman, J. Steiger, Earth-Sci. Rev. 106 (2011)

7. M., Tal, K., Gran, A.B., Murray, C. Paola, D.M., Hicks, Riparian Vegetation and Fluvial Geomorphology: Hydraulic, Hydrologic, and Geotechnical Interactions (American Geophysical Union, Washington D.C., 2004)

8. N. Pollen, Catena 69 (2007).

9. C.R. Thome, Vegetation and Erosion (Wiley, Chichester, 1990)

10. C.C. Fan, Y.W. Chen, Ecol. Eng. 36 (2010)

11. A. Simon, A.J.C. Collison, Earth Surf. Proc. Land. 27 (2002)

12. S. De Baets, J. Poesen, B. Reubens, K. Wemans, J. De Baerdemaeker, B. Muys, Plant Soil, 305 (2008)

13. A. Stokes, C. Atger, A.G. Bengough, T. Fourcaud, R.C. Sidle, Plant Soil 324 (2009)

14. K. Gran, C. Paola, Water Resour. Res. 37 (2001)

15. D.H. Gray, A.T. Leiser, Biotechnical Slope Protection and Erosion Control (VanNostrand Reinhold, New York, 1982)

16. Z.W. Li, G.A. Yu, G.J. Brierley, Z.Y. Wang, Y.H. Jia, Geomorphology, 276(2017)

17. Y.N. Chen, C.C. Xu, X.M. Hao, W.H. Li, Y.P. Chen, C.G. Zhu, Z.X. Ye, Quatern. Int. 208 (2009)

18. G.A. Yu, M. Disse, H.Q. Huang, Y. Yu, Z.W. Li, Catena, 147 (2016)

19. T.H. Wu, W.P. Mckinnell III, D.N. Swanston, Can. Geotech. J., 16 (1979)

20. G.B. Bischetti, E.A. Chiaradia, T. Simonato, B. Speziali, B. Vitali, P. Vullo, A. Zocco, Plant Soil, 278 (2005) 